\title{
Impact of mycorrhizal inoculation on the development of Intsia bijuga grown on soil under exotic species Casuarina equisetifolia plantation
}

\author{
Dina Ratahiriarisoa ${ }^{1,2,3, ~ *, ~ N i r i n a ~ C h r i s t o p h e ~ R a k o t o a r i m a n g a ~}{ }^{2}$, Rondro Harinisainana Baohanta ${ }^{2}$, \\ Herizo Randriambanona ${ }^{2}$, Marie-Ève.Beaulieu ${ }^{3}$, Damase Phambu Khasa ${ }^{3}$, \\ Marson Raherimandimby ${ }^{1}$ \\ ${ }^{1}$ Laboratory of Biotechnology - Microbiology, Faculty of Sciences, University of Antananarivo, Madagascar (LabMic), PO Box. 906, \\ Antananarivo 101, Madagascar \\ ${ }^{2}$ Laboratory of Environment Microbiology (LME), National Centre of Environnement Recherches (CNRE) Antananarivo, Madagascar, PO \\ Box. 1739, Antananarivo 101, Madagascar \\ ${ }^{3}$ Centre d'étude de la forêt (CEF) et Institut de biologie intégrative et de systèmes (IBIS), Université Laval, G1V 0A6, Québec, Québec, \\ Canada
}

\section{Email adress:}

din_arin@yahoo.fr (D. Ratahiriarisoa), manganir@yahoo.fr (N. C. Rakotoarimanga), ninish.rondro@yahoo.fr (R. H. Baohanta), zombanona@yahoo.fr (H. Randriambanona), Marie-Eve.Beaulieu@sbf.ulaval.ca (M-E Beaulieu),

Damase.Khasa@ibis.ulaval.ca (D. P. Khasa), marson.rahery@yahoo.com (M. Raherimandimby)

\section{To cite this article:}

Dina Ratahiriarisoa, Nirina Cristophe Rakotoarimanga, Rondro Harinisainana Baohanta, Herizo Randriambanona, Marie-Ève.Beaulieu, Damase Phambu Khasa, Marson Raherimandimby. Impact of Mycorrhizal Inoculation on the Development of Intsia bijuga Grown on Soil under Exotic Species Casuarina equisetifolia Plantation. Journal of Plant Sciences. Vol. 3, No. 1, 2015, pp. 14-21.

doi: $10.11648 /$ j.jps.20150301.13

\begin{abstract}
Installation of exotic species often influences the functioning of the soil microbial population and the development of indigenous plants. The objective of this study was to determine the influence of ectomycorrhizal inoculation on soil microorganisms and the development of the native plant Intsia bijuga grown on soils collected under exotic plantation of Casuarina equisetifolia. Two isolates of Pisolithus, Pis02 and PisE, were used to inoculate Intsia bijuga seedlings. After six months growth in a greenhouse, different parameters of plant development were evaluated: total biomass, mycorrhizal rate and chemical properties of leaves. For the rhizosphere soil, chemical and microbiological analyses were performed and enzyme activities were evaluated. The results showed that the inoculation of both ectomycorrhizal isolates caused a significant increase in phosphorus content in plant leaves and assimilable phosphorus content in soil cultures. In addition, the aboveground biomass of Intsia bijuga, the nitrogen content of leaves, the total microbial activity and the carbon content of the soil cultures were significantly higher with Pis 02 inoculation. However the intensity of the acid phosphatase and the numbers of solubilizing tricalcium phosphate microorganisms and actinomycetes were significantly reduced. This study highlighted the importance of mycorrhizae in the establishment of native plants in soils under exotic plantation.
\end{abstract}

Keywords: Ectomycorrhizal Symbiosis, Intsia Bijuga, Casuarina Equisetifolia, Soil Microbial, Enzymatic Activity

\section{Introduction}

In Madagascar, $10 \%$ of plant species that make up the flora are introduced [1]. Although these species are not well known, they occupy an important place in the functional and usable Malagasy biodiversity [1]. Casuarina equisetifolia is a native species of Australia, Melanesia and Southeast Asia [2]. This species is among the widely planted outside its natural range. Indeed, Casuarina equisetifolia is introduced in more than 60 countries [3]. In tropical countries, it is mostly used as plant reforestation of coastal soil [4] as the case of Madagascar.

In most cases, far from their native antagonists, exotic plants encounter favorable conditions for their development [5] and can colonize either fertile [6] or low nutrients soil by developing various mechanisms such as the fixation of atmospheric nitrogen [7]. The use of exotic species provides 
socio-economic and ecological benefits. However, ecological disruption is often associated with the use of certain exotic species [8]. In some island such as Nishi-Jima of Ogasawara group in Japan, much of the forest area has been replaced by Casuarina equisetifolia [9]. Other researchers found that exotic plants can alter the composition and function of microbial communities, the structure of the soil food web and nutrient cycling [10]. Some exotic trees greatly disturb island ecosystems by altering the structure of the native flora and fauna community [11-13], changing the nutrient cycle [12, $13]$ and decreasing the success of the regeneration of native trees [14]. More exotic species stimulate soil microbial community that promotes the acquisition of nutrients, abolish native symbiotic community and promote the development of indigenous communities' pathogens [15-17]. Some authors have questioned the possibility of regeneration of native trees in the forest of Casuarina equisetifolia [9] because of the chemistry of its litter. Indeed, it was found that actinorhizal nodule formation was inhibited by a certain amount of litter of Casuarina equisetifolia. This inhibition could be attributed to allelopathy phenomenon of phenolic compounds contained in the litter [18]. In addition, some experiments highlighted that the culture of Casuarina equisetifolia caused the decrease in the availability of essential soil nutrients including nitrogen [19].

The feedback between plant and soil plays a key role in the dynamics of plant communities, including plant succession [20] and soil restoration [21]. Some plants grown on poor soils benefited from the symbiosis with mycorrhizal fungi to develop [22]. Mycorrhizal fungi are responsible for the uptake and transport of soil nutrients with low mobility, such as phosphorus [23] and nitrogen [24] to the plant. In addition, mycorrhizal fungi and associated microorganisms are able to metabolize allelopathic compound [25], contribute to the protection of plants from the harmful substances released by exotic trees and enhance productivity [8].

Therefore, these organisms appear as a biological tool of great interest to improve plant growth, whether wild or cultivated, and also to restore soil [26-28]. Mycorrhizal associations play an important role in plant succession [29] and their effectiveness depends primarily on the ability of the fungus species to adapt to local conditions [30].

Thus, the objective of this study is to exploit the potential of ectomycorrhizal fungi to improve the establishment of Intsia bijuga on soil collected under the alien species Casuarina equisetifolia.

\section{Materials and Methods}

\subsection{Fungal Isolates}

Fungal isolates were obtained from fruiting bodies of ectomycorrhizal fungi collected during the rainy season. Fruit bodies of 2 Pisolithus species coded Pis02 and PisE were collected respectively in sclerophyllous forest located at Arivonimamo and under Pinus in Ankatso Antananarivo Madagascar. Pisolithus is a genus of ectomycorrhizal fungus that is widely distributed [31]. It forms a symbiotic association with many woody plants including members of Myrtaceae, Mimosaceae, Pinaceae, Fagaceae, Cistaceae, Dipterocarpaceae and Caesalpiniaceae. It can be encountered in various places like forest, plantations sites, mining sites and eroded sites [32].

Fungi were grown on modified Melin-Norkrans medium (MNM) [33]. MNM contains $0.05 \mathrm{~g} \mathrm{CaCl}_{2}, 0.025 \mathrm{~g} \mathrm{NaC1}$,

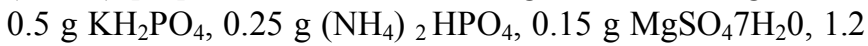
$\mathrm{ml}$ of $1 \% \mathrm{FeCl}_{3}, 100 \mu \mathrm{g}$ thiamine $\mathrm{HCl}, 3 \mathrm{~g}$ malt extract, and $10 \mathrm{~g}$ glucose per liter of distilled water. Agar was added to the MNM formulation at a concentration of $15 \mathrm{~g} / 1$. Fungal isolates were subsequently maintained at the Laboratory of Environmental Microbiology LME / CNRE Antananarivo by transplanting every month on solid culture medium MNM. The fungal inocula were prepared from these ectomycorrhizal isolates.

In each $250 \mathrm{ml}$ Erlen were placed $100 \mathrm{ml}$ of liquid MNM with 5 pieces of $1 \mathrm{~cm}^{2}$ of each ectomycorrhizal isolates. After incubation at $30{ }^{\circ} \mathrm{C}$ for a month, fungal hyphae that colonized the surface of the liquid medium were collected and washed with sterile distilled water (sterilized by autoclaving for $20 \mathrm{~min}$ at $120{ }^{\circ} \mathrm{C}$ ) then ground in $100 \mathrm{ml}$ sterile distilled water by using a blender at low speed for 10 s.

\subsection{Plant: Intsia Bijuga}

Intsia bijuga is a highly valued timber tree. It is a tree that adapts to coastal conditions and can be used in reforestation of coastal areas. It is also a native plant from Madagascar and other Island such as: Indonesia, Malaysia, Thailand, Philippines, Papua New Guinea, Guam, Australia, New Caledonia, Solomon Islands, Vanuatu, Fiji, Samoa, and Tonga. Intsia bijuga belongs to the family of Fabaceae and the subfamily of Caesalpinoideae [34]. In Madagascar it is known by the local name: Hintsy.

The seeds of Intsia bijuga were collected from the eastern part of Madagascar. They were scarified by soaking in a solution of concentrated sulfuric acid for 2 hours. The seeds were rinsed 5 times and soaked for 12 hours in sterile distilled water before germinating in a propagator containing sterilized sand (autoclaved at $120^{\circ} \mathrm{C}$ for $45 \mathrm{~min}$ )

\subsection{Soils}

Soils were collected in the forest of Tampolo, Fénérive, on the East coast of Madagascar. This forest is located at $17.3{ }^{\circ} \mathrm{S}$ latitude and $49.2^{\circ} \mathrm{E}$ longitude. For this, rhizosphere soils of Casuarina equisetifolia in $0-20 \mathrm{~cm}$ depth was taken.

\subsection{Experimental Design}

One germinated seed of Intsia bijuga was transplanted in each of $750 \mathrm{ml}$ sheaths of black plastic filled with sieved-soil (2mm mesh) collected under Casuarina equisetifolia. Each seedling was inoculated with $10 \mathrm{ml}$ of fungal inoculum of Pis02 or PisE at their root system. Each control plant received $10 \mathrm{ml}$ of fungal inoculum autoclaved at $120^{\circ} \mathrm{C}$ for $20 \mathrm{~min}$. Then, cultures were arranged in a block at total randomized system with 25 repetitions per treatment. 
Cultures were maintained in a greenhouse for 6 months under natural light with an approximate $12 \mathrm{~h}$ photoperiod and average temperature $25 \pm 2{ }^{\circ} \mathrm{C}$. The plants were watered with tap water twice a week.

\subsection{Parameters Evaluated}

To assess the impact of mycorrhiza on the development of Intsia bijuga on soils collected under Casuarina equisetifolia, three groups of parameters were measured after six months of culture: parameters related directly to the growth of the plant, parameters related to soil biofonctionning and soil chemical parameters.

\subsubsection{Parameters Directly Related to Plant Growth}

For each treatment, plant biomass, the rate of the mycorrhizal roots, $\mathrm{N}$ and $\mathrm{P}$ content of the leaves were measured. Dry weights of total biomass were recorded after oven-drying at $60^{\circ} \mathrm{C}$ for a week. To measure the mycorrhizal frequency, root tips of five randomly selected plants were observed under a dissecting microscope (magnification $\mathrm{x} 40$ ) and mycorrhizal apex are counted on 100 apex observed in a field of view.

The total $\mathrm{N}$ content of the leaves was determined by the Kjeldahl method [35] while the total $\mathrm{P}$ was determined by colorimetry with Molybdenum blue [36].

\subsubsection{Parameters Related to Soil Biofonctionning}

The total microbial activity and phosphatase activities of each soil including soil freshly collected under Casuarina equisetifolia were measured. In addition, cultivable phosphate solubilizing bacteria and actinomycetes were counted on each soil.

The total soil microbial activities were determined by the method described by [37]. Several enzymes can hydrolyze fluorescein diacetate (FDA) and the intensity of the enzymatic activity can be assessed by the amount of fluorescein hydrolysis product. The operation is to measure the quantity of fluorescein produced within 1 hour of incubation at $30^{\circ} \mathrm{C}$ by mixing $1 \mathrm{~g}$ of the soil sample with 200 $\mu 1$ of FDA solution. To the mixture of soil and FDA was added $15 \mathrm{ml}$ of phosphate buffer at $\mathrm{pH} 7.6$ prepared with $\mathrm{KH}_{2} \mathrm{PO} 4$ and $\mathrm{K}_{2} \mathrm{HPO} 4$. For each soil sample, three replicates were performed. The Fluorescein that was produced was evaluated spectrophotometrically. The absorbance readings were processed at $490 \mathrm{~nm}$. The total soil microbial activity was expressed in $\mu \mathrm{g}$ of fluorescein released per hour per $\mathrm{g}$ of soil ( $\mu \mathrm{g}$ fluorescéine. $\mathrm{h}^{-1} \cdot \mathrm{g}^{-1}$ of soil).

The soil phosphatase activities were determined by the method described by [38]. For phosphomonoesterase activity released into the soil, para-nitrophenylphosphate is hydrolyzed and releases para-nitrophenol. To $1 \mathrm{~g}$ of soil ( $0-2$ $\mathrm{mm}$ ) previously dried in the open air was added $1 \mathrm{ml}$ of $\mathrm{p}$ nitrophenylphosphate ( $\mathrm{pNP} 15 \mu \mathrm{g}$ ) and $4 \mathrm{ml}$ of buffer solution ("sterile modified universal buffer") at $\mathrm{pH} 6$ for acid phosphatase and $\mathrm{pH} 11$ for alkaline phosphatase. The samples were incubated at $37^{\circ} \mathrm{C}$ on a rotary shaker for $1 \mathrm{~h}$. The concentration of para-nitrophenol $(\mathrm{pN})$ produced was measured with spectrophotometer at $400 \mathrm{~nm}$ absorbance.

The results are expressed in micrograms of $\mathrm{pN}$ released per gram of sample and per hour of incubation time $(\mu \mathrm{g} \mathrm{pN}$ $\left.\mathrm{g}^{-1} \cdot \mathrm{h}^{-1}\right)$.

The number of rhizosphere microorganisms expressed as colony-forming units (CFUs) was evaluated by suspensiondilution method followed by spreading the solid media plate. Five grams of dried soil were placed in $100 \mathrm{ml}$ flasks and 45 $\mathrm{ml}$ of the sterilized solution of $\mathrm{MgSO}_{4}, 7 \mathrm{H}_{2} \mathrm{O} 1 \mathrm{M}$ was added. A sevenfold dilution series were performed by adding $0.9 \mathrm{ml}$ of distilled water at $0.1 \mathrm{ml}$ suspension of rhizosphere-soil water. Then $0.1 \mathrm{ml}$ of this mixture was spread in petri dishes containing a culture medium Waksman compound of $20 \mathrm{~g}$ glucose, $5 \mathrm{~g}$ casitone, $5 \mathrm{~g} \mathrm{NaCl}, 3 \mathrm{~g}$ beef extract and $20 \mathrm{~g}$ agar [39] for the enumeration of actinomycetes and Pivovskaya (PVK) compounds of $5 \mathrm{~g} \mathrm{NH}_{4} \mathrm{Cl} 1 \mathrm{~g}$ of $\mathrm{NaCl}, 1 \mathrm{~g}$ of $\mathrm{MgSO}_{4}$, $4 \mathrm{~g}$ of $\mathrm{Ca}_{3}$ (PO4) ${ }_{2}, 10 \mathrm{~g}$ of glucose and $20 \mathrm{~g}$ agar [40] for counting phosphate solubilizing bacteria. Three replicates per dilution were performed.

\subsubsection{Chemical Parameters of the Rhizosphere Soils}

For the rhizosphere soil, the amount of available $\mathrm{P}$ was determined by colorimetry with blue Molybdenum [33]; the content of total $\mathrm{N}$ was determined by the Kjeldahl method [35]; the $\mathrm{C}$ content was determined according to [41] and the $\mathrm{pH}$ was measured.

\subsection{Data Analysis}

Statistical analysis of the data obtained was performed using the Duncan test at 0.05 probability level and using the Statistica software (Kernel Version 5.1 million, Stat Soft, Inc).

\section{Results}

\subsection{Plant Growth, Mycorrhizal Rate, Nitrogen and Phosphorus Content of the Leaves}

Table 1. Shoot and root biomass, mycorrhizal rate, total nitrogen and phosphorus in leaves of Intsia bijuga after 6 months of culture.

\begin{tabular}{lllll}
\hline Treatments & Total biomass (g) & $\begin{array}{l}\text { Mycorrhizal } \\
\text { rate (\%) }\end{array}$ & N\% & P\% \\
\hline CONTROL & $2,5 \mathrm{a}^{*}$ & $65.59 \mathrm{a}$ & $2.77 \mathrm{~b}$ & $0.47 \mathrm{a}$ \\
PisE & $2,44 \mathrm{a}^{*}$ & $80.16 \mathrm{ab}$ & $2.56 \mathrm{a}$ & $0.49 \mathrm{~b}$ \\
Pis02 & $4,41 \mathrm{~b}$ & $92.40 \mathrm{~b}$ & $3.64 \mathrm{c}$ & $0.50 \mathrm{~b}$ \\
\hline
\end{tabular}

*: Values in the same column followed by the same letter are not significantly different according to Duncan's test at the 0.05 probability level CONTROL: soil under Intsia bijuga not inoculated; PisE: soil under Intsia bijuga inoculated with PisE; Pis02: soil under Intsia bijuga inoculated with Pis02.

Intsia bijuga grew differently with the two types of ectomycorrhizal inoculum. Indeed, biomass of plants inoculated with Pis02 was significantly higher compared with that of control plants and plants inoculated with PisE (Table 1). However, no significant differences were observed between the biomass of the control plants and the plants inoculated with PisE (Table 1). The nitrogen and phosphorus 
in the leaves and the frequency of mycorrhizal plants inoculated with Pis02 were significantly higher than those of the control plants (Table 1) while in the case of inoculation with PisE, only the phosphorus content in leaves of inoculated plants was significantly higher compared to control plants. It was found that the nitrogen content of the leaves of the plants inoculated with PisE was significantly lower than those of the control plants (Table 1).

\subsection{Enzyme Activities and Rhizosphere Microorganisms Counts}

The development of Intsia bijuga on the soil collected under Casuarina equisetifolia negatively affected the total microbial activity of the soil. Indeed, the intensity of the total soil microbial activity was significantly lower than the freshly collected soil under Casuarina equisetifolia (Table 2).
The intensities of the total microbial activities of the two soils were comparable when Intsia bijuga was inoculated with Pis02 (Table 2). The acid phosphatase activity of the soil collected under Casuarina equisetifolia was not influenced by the development of Intsia bijuga but the contrary occurred when Intsia bijuga was inoculated with Pis02 isolate.

Indeed acid phosphatase activity of the soil on which Intsia bijuga inoculated with Pis02 developed was significantly lower than the other soil (Table 2). The development of Intsia bijuga did not affect the alkaline phosphatase activity of the soil collected under Casuarina equisetifolia but negatively influenced the development of the complex phosphate solubilizing bacterial population and significantly stimulated the development of the actinomycetes population (Table 2).

Table 2. Total microbial activity, acid and alkaline phosphatase in rhizosphere soil after 6 months of the culture of Intsia bijuga under greenhouse.

\begin{tabular}{|c|c|c|c|c|c|}
\hline Treatments & $\begin{array}{l}\text { FDA } \\
\text { ( } \mu \mathrm{g} \text { of fluorescéine. } h^{-1} \cdot \mathrm{g}^{-1} \text { of soil). }\end{array}$ & $\begin{array}{l}\text { PAC } \\
\left(\mu \mathrm{g} \text { of p-nitrophénol.g } \mathrm{g}^{-1} \cdot \mathrm{h}^{-1}\right)\end{array}$ & $\begin{array}{l}\text { PAL } \\
\left(\mu \mathrm{g} \text { of p-nitrophénol.g } \mathrm{g}^{-1} \cdot \mathrm{h}^{-1}\right)\end{array}$ & TCP & ACTINO \\
\hline CTA0 (t0) & $46.15 b$ & $343.33 b^{*}$ & $22.69 a$ & $8400 b$ & $674 a$ \\
\hline CONTROL & $27.64 a$ & $231.34 b^{*}$ & $72.69 \mathrm{a}$ & $750 \mathrm{a}$ & $13500 \mathrm{c}$ \\
\hline PisE & $25.05 \mathrm{a}$ & $233.80 \mathrm{~b}$ & $85.95 \mathrm{a}$ & $626.66 \mathrm{a}$ & $13400 \mathrm{c}$ \\
\hline Pis02 & $50.78 \mathrm{~b}$ & $57.46 \mathrm{a}$ & $19.52 \mathrm{a}$ & $400 \mathrm{a}$ & $8366.66 \mathrm{~b}$ \\
\hline
\end{tabular}

*: Values in the same column followed by the same letter are not significantly different according to Duncan's test at the 0.05 probability level

FDA: total microbial activity; PAC: acid phosphatase, PAL: alkaline phosphatase.

CTA0 (t0): soil under Casuarina equisetifolia. CONTROL: soil under Intsia bijuga not inoculated; PisE: soil under Intsia bijuga inoculated with PisE; Pis02: soil under Intsia bijuga inoculated with Pis02.

TCP: phosphate solubilizing microorganisms; ACTINO: Actinomycetes.

\subsection{Chemical Analyzes of Rhizosphere Soil}

After six months growing, soil $\mathrm{pH}$ on which Intsia bijuga was grown was significantly lower compared with the other soil while the total nitrogen levels were significantly higher (Table 3). The development of Intsia bijuga negatively influenced the rate of available phosphorus in the rhizosphere soil, but for the soils that developed Intsia bijuga inoculated with fungal isolates PisE, Pis02, the rate of phosphorus was significantly higher (Table 3 ).

The total carbon content of the soil on which Intsia bijuga inoculated with Pis02 developed was much higher than other soils (Table 3).

Table 3. Chemical analysis of soil under Casuarina equisetifolia and rhizosphere soil after 6 months of the culture of Intsia bijuga.

\begin{tabular}{llllll}
\hline Treatments & $\mathbf{p H}(\mathbf{e a u})$ & $\mathbf{N} \%$ & $\mathbf{P}(\mathbf{p p m})$ & $\mathbf{C} \%$ & $\mathbf{C} / \mathbf{N}$ \\
\hline CTA0 $(\mathrm{t} 0)$ & $6.34 \mathrm{~d}$ & $0.07 \mathrm{a}$ & $4.90 \mathrm{~b}$ & $1.49 \mathrm{ab} *$ & $21.60 \mathrm{c}$ \\
Control & $5.68 \mathrm{c}$ & $0.12 \mathrm{c}$ & $2.75 \mathrm{a}$ & $1.55 \mathrm{~b}^{*}$ & $13.02 \mathrm{a}$ \\
PisE & $5.42 \mathrm{~b}$ & $0.09 \mathrm{~b}$ & $7.33 \mathrm{~d}$ & $1.39 \mathrm{a}$ & $15.27 \mathrm{~b}$ \\
Pis02 & $5.32 \mathrm{a}$ & $0.12 \mathrm{c}$ & $5.33 \mathrm{c}$ & $1.77 \mathrm{c}$ & $14.59 \mathrm{ab}$ \\
\hline
\end{tabular}

*: Values in the same column followed by the same letter are not significantly different according to Duncan's test at the 0.05 probability level FDA: total microbial activity; PAC: acid phosphatase, PAL: alkaline phosphatase.

CTA0 (t0): soil under Casuarina equisetifolia. CONTROL: soil under Intsia bijuga not inoculated; PisE: soil under Intsia bijuga inoculated with PisE; Pis02: soil under Intsia bijuga inoculated with Pis02.

\section{Discussion}

Our results show that compared to non-inoculated control plants, mycorrhizal rate, the total biomass, $\mathrm{P}$ and $\mathrm{N}$ content in leaves of Intsia bijuga inoculated with mycorrhizal isolate Pis02 were significantly high. Several authors showed that mycorrhizal plants stimulated the growth of biomass [42-48]. According to these authors, the improved growth of biomass was $37 \%$ to $350 \%$. Trappe J. and al cited by [30] found an improvement in the growth of conifer Tsuga heterophylla by inoculation with four ectomycorrhizal strains (Hebeloma crustuluniforme, Laccaria laccata, Pisolithus tinctorius, Thelephora terrestris). The highest biomass was obtained with Pisolithus tinctorius. Numbers of authors highlighted that mycorrhize significantly improves phosphate $[45,47$, 49- 53] and nitrogen nutrition of the plant [24, 54-59]. However, the effectiveness of mycorrhizal depends mainly on the fungal strain that colonizes the plant [60]. In our case inoculation with mycorrhizal isolate PisE did not affect the total biomass of Intsia bijuga and negatively influenced the nitrogen content in the leaves of the plant. These results suggest that Pis02 is more effective than PisE to the development of Intsia bijuga on soil collected under Casuarina equisetifolia. It should be noted that noninoculated plants (control) were mycorrhizal. This showed that in the soil under Casuarina equisetifolia developed mycorrhizal strains which can infect Intsia bijuga. This is the case, among others, of a fungal sharing between two native 
species (Fagaceae and Betulaceae) surrounding an alien species (Pinaceae) in Iran [61].

Some authors reported that competition for nitrogen nutrition can take place between the host plant and its fungal partner [62] and other authors illustrated the competition between different fungal strains [63] while the growth of the plant requires high nitrogen content [64]. It was reported that competition negatively affects the ability of ectomycorrhizal fungi to provide benefits to the host plant [65].

Plants inoculated with Pis02 showed a significant higher rate of mycorrhizal compared to control plants. This result suggests that Pis02 massively colonizes the roots of Intsia bijuga contrary to the case of PisE. Some authors showed that the effective ectomycorrhizal strain for the plant growth was that strongly colonized the root of the plant [45]. Similar results on the relationship between plant growth and abundance of ectomycorrhizal root colonization was observed by other authors [66, 67].

However, it has shown that the ability of ectomycorrhizal fungi to colonize root does not always explain their effectiveness $[68,69]$ and the high rate of mycorrhiza does not prejudge its effectiveness on plant growth [70]. Some authors found no correlation between the stimulation of plant growth and degree of mycorrhizal infection [71]. It has found that the root symbiosis with the ectomycorrhizal fungus Laccaria laccata has developed more hyphae than the other fungus without giving apparent benefits to the plant [45]. However, some ectomycorrhizal fungi isolates as Cortinarius, Amanita, Hysterangium promoted the growth of the plant without colonizing massively the root [45]. In our case, although the mycorrhizal strain PisE not massively colonizes the roots of Intsia bijuga, the phosphorus content of plants was significantly high. This is a positive effect on phosphorus uptake. Furthermore, mycorrhizal symbiosis, even without being involved in the apparent growth of the plant could contribute to its health protection [72] or to the fight against the stress caused by the new environment [73, 74].

Our result showed that the acid phosphatase activity of soil collected under Casuarina equisetifolia was negatively affected by the development of Intsia bijuga inoculated with mycorrhizal isolate Pis02. Soil biofonctionning depends largely on the composition of root exudates [75, 76] which itself depends on the species of the plant [77] or the species of fungus that colonizes the root $[75,78]$. In our experience, the acid phosphatase of the fungus was not measured. This suggests that Pis02 has a very intense acid phosphatase activity for releasing a large quantity of available $\mathrm{P}$ which in turn inhibits the development of other microorganisms having an acid phosphatase activity. Several studies showed that the increase in phosphatase activity around the root led a formation of a depletion zone in organic $\mathrm{P}$ thus reflecting the effectiveness of these enzymes for the release of the Pi from organic $\mathrm{P}$ in favor of the root $[79,80]$.

It was found that the structure and diversity of rhizosphere microorganisms of mycorrhizal plants depend largely on the quality of mycorrhizal hyphae exudates [78]. The acid phosphatase activity of ectomycorrhizal fungi was illustrated by [81]. The root exudate of each plant that is secreted in large amounts in the rhizosphere contains compounds that are specific to it, affects the soil macro and microorganisms [82] and builds the structure of rhizosphere microorganisms. The latter differs by their ability to metabolize and compete the different carbon sources [83]. In our case, it seems that the root exudate of Intsia bijuga stimulates the development of actinomycetes initially present in the soil of culture and does not favor the population of solubilizing phosphate bacteria. This result is in line with that found by [84]. According to them, the community of rhizosphere bacteria of the same soil type is not the same under two different plant species.

In addition, the decrease in soil $\mathrm{pH}$, which is often in relation to the root exudate composition [85] resulted in the release of soil inorganic phosphate, which increases the amount of available phosphorus to the plant [86].

Our results showed that the soil on which developed Intsia bijuga inoculated with mycorrhizal isolate Pis02 had high significant carbon content. This result could be explained by the massive colonization of the root by mycorrhizal isolate. Indeed, some authors showed that ectomycorrhizal biomass accounts for about $15 \%$ of the organic matter in forest soils $[87,88]$. Mycorrhizal tissues are a significant source of carbon in the ecosystem [87-92].In addition, some ectomycorrhizal fungi are able to degrade nutrients and carbon-rich molecules in the soil and litter [93-95] such as C-rich biopolymers like cellulose, pectin, and fats [95].

\section{Conclusion}

Intsia bijuga develops by establishing ectomycorrhizal symbiosis on the soil collected under Casuarina equisetifolia. Intsia bijuga development has significantly improved with mycorrhizal fungal isolate Pis02, fungus collected in sclerophyllusforest. Improved reforestation with native plants on different soil types is possible by mastering the mycorrhizal symbiosis.

\section{References}

[1] C. A. Kull, J. Tassin, S. Moreau, H. R. Ramiarantsoa, C. BlancPamard, S. M. Carriere, "The introduced flora of Madagascar," Biol. Invasion, vol. 14, pp. 875-888, 2012.

[2] J. A. Parrotta, "Casuarina equisetifolia L.ex J.R \& G. Forst," SO-ITF-SM-56, pp. 1-11, 1993.

[3] K. Pinyopusarerk, M. Barrie, "Improvement and culture of Nitrogen Fixing Trees", NFT News, vol.4 No.1, 2001.http://iufro.boku.ac.at/iufro/iufronet/d2/wu20802/nl20802.htm

[4] L -H. Zhang, Y-M. Lin, G -F. Ye, X -W. Liu, G -H. Lin, "Changes in the $\mathrm{N}$ and $\mathrm{P}$ concentrations, $\mathrm{N}$ : $\mathrm{P}$ ratios and tannin content in Casuarina equisetifolia branchlets during development and senescence," J. For. Res., vol.13, pp.302-311, 2008 .

[5] C. E. Mitchell, A. G. Power,"Release of invasive plants from viral and fungal pathogens," Nature vol. 421, pp. 625-627, 2003. 
[6] P. B. Bridgewater, D. J. Backshall,"Dynamics of some Western Australian ligneous formations with special reference to the invasion of exotic species," Vegetatio vol. 46, pp. 141$148,1981$.

[7] P. M. Vitousek, L. R. Walker, L. D. Whiteaker, D. MuellerDombois, and P. A. Matson, "Biological invasion by Myrica fayaalters ecosystem development in Hawaii," Science, vol. 238, pp.802-804, 1987.

[8] A. Dia, R. Duponnois, "La grande muraille verte: capitalisation des recherches et valorisation des savoirs locaux," IRD, Eds. 496p, 2012.

[9] T. Abé, T. Yasui, S. Mackino, "Vegetation status on Nishi-jima Island (Ogasawara) before eradication of alien herbivore mammals: rapid expansion of an invasive alien tree, Casuarina equisetifolia (Casuarinaceae)," J. For. Res. vol.16, pp. 484-491, 2011.

[10] D. Scharfy, S. Gusewell, M. O. Gessner, H. O. Venterink, "Invasion of Solidago gigantea in contrasting experimental plant communities: effects on soil microbes, nutrients and plant-soil feedbacks," Journal of Ecology, vol.98, pp.13791388,2010

[11] J. Y. Meyer, J. Florence, "Tahiti's native flora endangered by the invasion of Miconia calvescens DC. (Melastomataceae)," J. Biogeogr.vol.23, pp. 775-781, 1996.

[12] P. F. Hughes, J. S. Denslow, "Invasion by a N2-fixing tree alters function and structure in wet lowland forests of Hawaii," Ecol. Appl., 15, pp. 1615-1628, 2005.

[13] N. C. Tuttle, K. H. Beard, W. C. Pitt, "Invasive litter, not an invasive insectivore, determines invertebrate communities in Hawaiian forests,” Biol. Invasions, vol.11, pp.845-855, 2009.

[14] S. Cordell S, R. Ostertag, B. Rowe, L. Sweinhart, L. VasquezRadonic, J. Michaud, T. C. Cole, J. R. Schulten, "Evaluating barriers to native seedling establishment in an invaded Hawaiian lowland wet forest," Biol. Conserv., vol. 142, pp. 2997-3004, 2009.

[15] C. V. Hawkes, I. F. Wren, D. J. Herman \& M. K. Firestone "Plant invasion alters nitrogen cycling by modifying the soil nitrifying community," Ecology Letters, vol.8, pp.976-985, 2005 .

[16] B. E. Wolfe \& J. N. Klironomos, Breaking new ground: soil communities and exotic plant invasion. BioScience, vol.55, pp.477-487, 2005.

[17] M. B. Eppinga, M. Rietkerk, S, C. Dekker, P. C. De Ruiter, W. H. Van Der Putten, "Accumulation of local pathogens: a new hypothesis to explain exotic plant invasions," Oikos, vol. 114, pp. 168-17, 2006.

[18] W. F. Sayed, H. M. El-Sharouny, H. H. Zahran, W. M. Ali, "Composition of Casuarina leaf litter and its influence on Frankia-Casuarina symbiosis in soil," Folia Microbiol, vol.47, N.4, pp.429-434. 2002,

[19] X. Liu, Y. Lu, Y. Xue, X. Zhang, "Testing the importance of native plants in facilitation the restoration of coastal plant communities dominated by exotics," Forest Ecology and Management, vol. 322, pp.19-26, 2014.

[20] P. Kardol, T. M. Bezemer, W. H. Van Der Putten, "Temporal variation in plant-soil feedback controls succession," Ecology Letters, vol. 9, pp.1080-1088, 2006.
[21] V. T. Eviner, C. V. Hawkes, "Embracing variability in the application of plant-soil interactions to the restoration of communities and ecosystems," Restoration Ecology, vol. 16, pp.713-729, 2008.

[22] P. J. Davis, "Mycorhizae Influence Tropical Succession," Biotropica, Vol. 12, $\mathrm{N}^{ } 2$, supplement: Tropical Succession, pp. 56- 64, 1980.

[23] M.A. Selosse, F. Richard, X. He, S. W. Simard, "Mycorrizal networks: des liaisons dangereuses?" Trends Ecol. Evol. 21: 621-628, 2006.

[24] K. Valtanen, V. Eissfeller, F. Beyer, D. Hertel, S. Scheu, A. Polle, Carbon and nitrogen fluxes between beech and their ectomycorrhizal assemblage. Mycorrhiza, 2014.

[25] U. Blum, K. L. Staman, L. J. Flint, S. R. Shafer, "Induction and/or selection of phenolic acid-utilizing bulk-soil and rhizosphere bacteria and their influence on phenolic acid phytotoxicity,” J. Chem. Ecol, vol. 26, pp. 2059-2078, 2000.

[26] G. J. Bethlenfalvay, H. Schüepp, “Arbuscular mycorrhizas and agrosystem stability, in Impact of arbuscular mycorrhizas on Sustainable Agriculture and Natural Ecosystems, Gianinazzi S. Schüepp H, Eds. Birkhauser Verlag; Basel, Switzerland, 1994, pp: 117-137.

[27] J. F. Johansson, L. R. Paul, R. D. Finlay,"Microbial interactions in the mycorrhizosphere and their significance for sustainable agriculture," FEMS Microbiol. Ecol., vol 48, pp. 1-43, 2004.

[28] F. Gentili, A. Jumpponen, "Potential and possible uses of bacterial and fungal biofertilizes," in Handbook of Microbial Biofertilizers, M. K. Rai, Eds. Food Products Press, pp. 1-28, 2006

[29] M. M. Hart, J. Richard, Reader and J. N. Klironomos," Plant coexistence mediated by arbuscular mycorrhizal fungi," TRENDS in Ecology and Evolution, vol.18 No.8, 2003.

[30] J. M. Trappe,"Selection of fungi for ectomycorrizal inoculation in nurseries," Ann. Rev. Phytopathol, vol.15, pp.203-222, 1977.

[31] S. M. Chambers and J. W. G. Cairney. Pisolithus, "In Ectomycorrhizal Fungi: key genera in profile", J. W. G. Cairney \& S.M.Chambers, Eds. Springer-Verlag, Berlin, 1999, pp. $1-31$

[32] J. H. Gardner and N. Malajczuk. Recolonization of rehabilitated bauxite mine sites in Western Australia by mycorrhizal fungi. For. Ecol. Manage, vol. 24, pp.27-42, 1988.

[33] D. H. Marx, "The influence of ectotrophic mycorrhizal fungi on the resistance of pine roots to pathogenic infections. I. Antagonism of mycorrhizal fungi to root pathogenic fungi and soil bacteria, Phytopathol," vol. 59, pp. 153-163, 1969.

[34] R. R. Thaiman, L. A. J. Thomson, R. DeMeo, F. Areki, and C. R. Elevitch,“ Intsia bijuga (vesi). Species Profiles for Pacific Island Agroforestry," www.traditionaltree.org. ver.3-I, 2006.

[35] M. K. John, "Colorimetric determination in soil and plant material with ascorbic acid," Soil Science, vol. 68: pp. 171$177,1970$.

[36] J. Murphy, J. P. Riley, "A modified single solution method for the determination of phosphate in natural waters," Anal. Chim. Acta, vol. 27, pp.31-35, 1962. 
[37] J. Schnürer, T. Rosswall, "Fluorescein diacetate hydrolysis as a measure of total microbial activity in soil and litter," Applied and Environmental Microbiology, vol.6, pp.1256-1261, 1982.

[38] M. A. Tabatabai, "Assay of enzymes in soil," in Methods of Soil Analysis, Vol. 2 (ed. A.L. Page), Am.Soci Agron and Soil Sci., Madison, WI, pp.922-947, 1982.

[39] S. A. Waksman, "The Actinomycetes, Classification, Identification and Description of Genera and Species," Baltimore: The Williams and Wilkins Company, vol. 2 pp. 61292, 1961.

[40] R. I. Pivovskaya,"Mobilization of phosphates in soil in connection with the vital activities of some microbial species," Mikrobiologia, vol.17, pp. 362-370, 1948.

[41] G. Aubert, Méthodes d'Analyse des sols, CRDP Ed., Marseille, 1978, p. 360.

[42] J. Garbaye, J. C. Delwaulle, D. Diangana, "Growth response of eucalypts in the Congo to ectomycorrhizal inoculation," Forest. Ecol. Manag., vol. 24, pp.151-157, 1988.

[43] O. Osonubi, K. Mulongoy, O. O. Awotoye, and D. U. V. Okali, "Effects of ectomyorrhizal and vesicular-arbuscular mycorrhizal fungi on drought tolerance of four leguminous woody seedlings," Plant Soil, vol. 136, pp. 131-143, 1991.

[44] P. Reddell, Y. Prin, C. Theodorou, "Growth responses in Acacia mangium to inoculation with ectomycon'hizal fungi," in International Symposium, D. Jasper and B. Thomson, Eds., 1992.

[45] B. D. Thomson, T. S. Grove, N. Malajczuk and G. E. STJ. Hardy, The effectiveness of ectomycorrhizal fungi in increasing the growth of Eucalyptusglobulus Labill.in relation to root colonization and hyphal development in soil. New Phytol.126, 517-524, 1994.

[46] Y. L. Chen, L. H. Kang, N. Malajczuck, B. Dell, "Selecting ectomycorrhizal fungi for inoculating plantations in south China: effect of Scleroderma on colonization and growth of exotic Eucalyptus globulus, E. urophylla, Pinus elliottii, and $P$. radiate," Mycorrhizavol. 16, pp. 251-259, 2006.

[47] C. B. Bati, E. Santilli, L. Lombrado, "Effect of arbuscular mycorrhizal fungi on growth and on micronutrient and macronutrient uptake and allocation in olive plantlets growing under high total Mn levels," Mycorrhiza, 2014.

[48] A. R. Franco, P. M. L. Castro,"Inoculation of Pinus pinea seedlings with Pisolithus tinctorius and Suillus bellinii promotes plant growth in benfluralin contaminated soil," Plant Soil, 2014.

[49] D. Mousain, N. Poitou, J. Delmas, "La Symbiose mycorhizienne : résultats obtenus avec l'Hebeloma cylindrosporumet le Pisolithus tinctorius, et perspectives d'application agronomique," inMushroom Science X (Part I), Proceedings of the 10th International Congress on the Science and Cultivation of Edible Fungi (France, juin 1978) / J. Delmas Ed. Bourges : Tardy Quercy SA, pp 949-956, 1979.

[50] A. B. Hatch,"The physical basis of mycotrophy in the genus Pinus,"Black Rock For. Bull, vol. 6, pp. 1-168, 1937.

[51] D. Mousain, "Étude de la nutrition phosphatée de symbiotes ectomycorhiziens," Montpellier : Université des Sciences et Techniques du Languedoc (Thèse de Doctorat d'État en Sciences), 1989.
[52] N. S. Bolan, "A critical review on the role of mycorrhizal fungi in the uptake of phosphorus by plants," Plant Soilvol. 134, pp. 189-207, 1991.

[53] L. A. Borges De Souza, P. A. P. Bonnassis, G. N. S. Filho, V. Lopes De Oliveira, "New isolates of ectomycorrhizal fungi and the growth of eucalypt," Pesq. Agropec.Bras.Brasília, vol. $43 \mathrm{n}$. 2, pp. 235-241, 2008.

[54] F. Martin, Lorillou, "Nitrogen acquisition and assimilation in ectomycorrhizal systems," in: Trees-contributions to modern tree physiologyH. Rennenberg, W. Eschrich, H. Ziegler, Eds. SPB Academic Publ., La Haye, Pays-Bas, pp. 423-439, 1997.

[55] J. P. Schimel, J. Bennett, "Nitrogen mineralization: challenges of a changing paradigm," Ecology, vol.85, pp.591-602, 2004.

[56] H. Lambers, J. A. Raven, G. R. Shaver, S. E. Smith, "Plant nutrient-acquisition strategies change with soil age," Trends in Ecology and Evolution, vol. 23, pp.95-103, 2008.

[57] H. Lambers, C. Mougel C., Jaillard B., Hinsinger P. 2009. Plant-microbe-soil interactions in the rhizosphere: an evolutionary perspective. Plant and Soil 321:33 p

[58] A. E. Richardson, J -M. Barea, A.M. Mcneill, C. PrigentCombaret, "Acquisition of phosphorus and nitrogen in the rhizosphere and plant growth promotion by microorganisms," Plant and Soil, vol. 321, pp.305-339, 2009.

[59] J. Talbot, K. Treseder, Controls over mycorrhizal uptake of organic nitrogen," Pedobiologia, vol.53, pp.169-179, 2010.

[60] P. G. Kennedy, H. Hortal, S. E. Bergemann, T. D. Bruns, "Competitive interactions among three ectomycorrhizal fungi and their relation to host plant performance," Journ. of Ecol., vol.95, pp. 1338-1345, 2007.

[61] M. Braham, U. Kõljalg, P. Kohout, S. Mirshahvaladi, L. Tedersoo, "Ectomycorrhizal fungi of exotic pine plantations in relation to native host trees in Iran: evidence of host range expansion by local symbionts to distantly related host taxa," Mycorrhiza, vol. 2, pp. 311-19, 2013.

[62] J. Colpaert, J. A. Van Asshe, A. K. Luitjens, "The growth of the extramatrical mycelium of ectomycorrhizal fungi and the growth response of Pinus sylvestris L.," New Phytol., vol. 120, pp 127-135, 1992.

[63] J. P. Daniel, E. Engelmoer Jocelyn, Behm, E. Toby Kiers, "Intense competition between arbuscular mycorrhizal mutualists in an in vitro root microbiome negatively affects total fungal abundance," Mol. Ecol., 2013.

[64] B. P. Mark, S. P. John, A. A. Craig, "Mobilization of nitrogen in fruiting plants of a cultivar of cowpea," J. Exp. Bot., vol. 34, n.5, pp.563-578, 1983.

[65] P. G. Kennedy, S. Hortal, S. E. Bergemann, T. D. Bruns, "Competitive interactions among three ectomycorrhizal fungi and their relation to host plant performance," Journ. of Ecol.95 , 1338-1345, 2007.

[66] M. L. Cline, C. P. P. Reid, "Seed source and mycorrhizal fungal effects on growth of containerized Pinus contorta and Pinus ponderosa seedlings," Forest Science vol. 28, pp.237-250, 1982.

[67] P. A. Heinrich, J. W. Patrick, "Phosphorus acquisition in the soil-root system of Eucalyptus pilularis Smith seedlings. The effect of ectomycorrhizas on seedling phosphorus and dry weight acquisition," Aust. Journ.of Bot., vol. 34, pp.445-54, 1986. 
[68] J. H. Graham, R. G. Linderman, J. A. Menge, "Development of external hyphae by different isolates of mycorrhizal Glomus spp. in relation to root colonization and growth of troyer citrange," New Phytol. Vol.91, pp.183-189, 1982b.

[69] M. D. Jones, D. M. Durall, P. B. Tinker,"Phosphorus relationships and production of extramatrical hyphae by two types of willow ectomycorrhizas at different soil phosphorus levels," New Phytol., vol. 115, pp.259-267, 1990.

[70] T. Guissou, A. M. Ba, C. Plenchette, S. Guinko, R. Duponnois, "Effets des mycorhizes à arbuscules sur la tolérance à un stress hydrique de quatre arbres fruitiers: Balanites aegyptiaca (L.) Del., Parkia biblobosa (Jacq.) Benth., Tamarindus indicaL. et Zizyphus mauritianaLam," Secheressen 2, vol.12, 2001.

[71] H. Boukcim, S. Conventi, D. Mousain, 'Ectomycorhization de Cedrus atlantica en conditions contrôlées : efficacité de deux formes d'inoculum mycélien," Ann. For Sci., vol. 59, pp. 839846, 2002.

[72] C. L. N. Rosendahl, S. L. Rosendahl, "The role of vesiculararbuscular mycorrhizal fungi in controlling damping-off and growth reduction in cucumber caused by Pythium ultimum,"Symbiosis, vol.9, pp.363-366, 1990.

[73] M.C. Brundrett, "Mycorrhizas in natural ecosystems," in Advances in ecological research vol. 21, A. Macfayden, M. Begon, A. H. Fitter, Eds. London, UK: Academic Press, 1991, pp. 171-313.

[74] D. G. Strullu, "Les mycorhizes des arbres et plantes cultivées,"Collection Tech. \& Doc., Lavoisier, Paris, 1991.

[75] G. Andrade, R. G. Linderman, Bethlenfalvay, "Bacterial associations with the mycorrhizosphere and hyphosphere of the arbuscular mycorrhizal fungus Glomus mosseae," Plant and Soil,vol. 202, pp. 79-87, 1998.

[76] R. N. Ames, C. P. P. Reid, Reid and R. Inghame,"Rhizosphere bacterial population responses to root colonization by a vesicular-arbuscular mycorrhizal fungus," New Phytol, vol. 96, pp. 555- 563, 1984.

[77] P. Lemanceau, T. Corberand, L. Gardan, X. Latour, G. Laguerre, J-M. Boeufgras, C. Labouvette, "Effect of Two Plant Species, Flax (Linum usitatissinum L.) and Tomato (Lycopersicon esculentum Mill.), on the Diversity of Soilborne Populations of Fluorescent Pseudomonads.” Apl and Envir. Microbiol, pp.1004-1012, 1995.

[78] G. Andrade, K. L. Mihara, R. G. Linderman, G. J. Bethlenfalvay, "Bacteria from rhizosphere and hyphosphere soils of different arbuscular-mycorrhizal fungi," Plant and Soil, vol. 192, pp. 71-79. 1997.

[79] J. C. Tarafdar, A. Jungk, "Phosphatase activity in the rhizosphere and its relation to the depletion of soil organic phosphorus," Bio. Fert.Soils.vol.3, pp.199-204, 1987.

[80] T. S. George, B. L. Turner, J. P. Gregory, B. J. Cade-Menun, A. E. Richardson, "Depletion of organic phosphorus from oxisols in relation to phosphate activities in the rhizosphere," Eur. J. Soil Sci., vol.57, pp. 47-57, 2006.
[81] Y. Tasaki, A. Azwan, Y. Yasaki, T. Hara, T. Joh, "Structure and expression of two genes encoding secreted acid phosphatases under phosphate-deficient conditions in Pholiota nameko strain N2," Curr.Genet., vol.49, pp.323-332, 2006.

[82] C. Bertin, X. Yang, L.A. Weston, "The role of root exudates and allelochemicals in the rhizosphere," Plant and Soil, vol.256, pp. 67-83, 2003.

[83] P. Marchner, S. Timonen, "Interactions between plant species and mycorrhizal colonization on the bacterial community composition in the rhizosphere," Applied Soil Ecology, vol. 28, pp. 23-36, 2005.

[84] P. Marschner, C-H. Yang, R. Lieberei, D. E. Crowley,“Soil and plant specific effects on bacterial community composition in the rhizosphere," Soil Biol. Biochem, vol. 33, pp. 1437 $1445,2001 b$.

[85] H. Marschner, "Mineral nutrition of higher plants, 2nd edition," Academic press, London, 1995.

[86] D. Riley, S. A. Barber, "Effect of ammonium and nitrate fertilization on phosphorus uptake as related to root-induced $\mathrm{pH}$ changes at the root-soil interface," Soil Sci. Soc. Am. Proc., vol.35, pp.301-306, 1971.

[87] K. A. Vogt, C. C. Grier, C. E. Meier, R. L. Edmonds, "Mycorrhizal role in net primary production and nutrient cycling in Abies amabilis ecosystems in western Washington," Ecology, vol.63, pp.370-380, 1982.

[88] K. A.Vogt, D. A. Publicover, D. J. Vogt, "A critique of the role of ectomycorrhizas in forest ecology," Agri.Ecosys.and Envir, vol.35, pp.171-190, 1991.

[89] R. Fogel, G. Hunt, "Contribution of mycorrhizae and soil fungi to nutrient cycling in a Douglas-fir ecosystem," Can. Journ.of For. Res. vol. 13, pp. 219-232, 1983.

[90] E. G. O'Neill, Responses of soil biota to elevated atmospheric carbon dioxide. Plant and Soil, vol. 65, pp.55-65, 1994.

[91] M. F. Allen, S. J. Morris, F. Edwards, E. B. Allen, "Microbeplant interactions in Mediterranean-type habitats: shifts in fungal symbiotic and saprophytic functioning in response to global change," in Global change and Mediterranean-type ecosystems, J. M. Moreno, W. C. Oechel, Eds. New York, USA: Springer Verlag, 1995, pp. 287-305.

[92] M. C. Rillig, M. F. Allen, "What is the role of arbuscular mycorrhizal fungi in plant-to-ecosystem responses to elevatedatmospheric $\mathrm{CO}_{2}$ ?" Mycorrhiza, vol.9, pp.1-8, 1999.

[93] J. M. Talbot, S. D.Allison, K. K. Treseder, "Decomposers in disguise: mycorrhizal fungi as regulators of soil $\mathrm{C}$ dynamics in ecosystems under global change," Functional Ecology, vol. 22, pp.955-963, 2008.

[94] D. J. Read, J. Perez-Moreno, "Mycorrhizas and nutrient cycling in ecosystems a journey toward relevance?" New Phytol., vol.157, pp. 475-492, 2003.

[95] J.Talbot, K. Treseder,"Controls over mycorrhizal uptake of organic nitrogen," Pedobiologia, vol.53, pp. 169-179, 2010. 